\title{
Erratum to: Effects of the foliar application of calcium on photosynthesis, reactive oxygen species production, and changes in water relations in tomato seedlings under heat stress
}

\author{
Siriwat Sakhonwasee ${ }^{*}$ and Wanalee Phingkasan \\ Program in Horticulture, Faculty of Agricultural Production, Maejo University, Chiang Mai 50290, Thailand \\ *Corresponding author: siriwat@mju.ac.th
}

(C) Korean Society for Horticultural Science and Springer 2016

Erratum to: Hortic. Environ. Biotechnol. 58(2):119-126. 2017.

DOI 10.1007/s13580-017-0194-1

The original version of this article contained an error in the abstract.

The correct abstract should be written as follow.

\begin{abstract}
Many studies have investigated the impact of a single calcium salt on plant physiology under heat-stress, but it is difficult to determine the effect of calcium from those of its counterions. To address this, we investigated calcium-mediated heat tolerance in tomato seedlings using foliar sprays of four different salt solutions: $\mathrm{CaCl}_{2}, \mathrm{CaNO}_{3}$, $\mathrm{MgCl}_{2}$ or $\mathrm{KNO}_{3}$. The application of $\mathrm{CaCl}_{2}$ and $\mathrm{CaNO}_{3}$ improved the operating efficiency of photosystem II (PSII) in the light-adapted state $\left(\Phi_{\mathrm{PSII}}\right)$, maximum quantum efficiency of PSII in the dark-adapted state $\left(\mathrm{F}_{\mathrm{v}} / \mathrm{F}_{\mathrm{m}}\right)$, and the $\mathrm{CO}_{2}$ assimilation rate under the heat-stress condition. In contrast, the application of $\mathrm{MgCl}_{2}$ and $\mathrm{KNO}_{3}$ had no significant effect on those parameters. The application of $\mathrm{CaCl}_{2}$ and $\mathrm{CaNO}_{3}$ resulted in a lower production of hydrogen peroxide, superoxide, and cell death than the heat-stressed control plants. The application of $\mathrm{MgCl}_{2}$ and $\mathrm{KNO}_{3}$ also resulted in lower hydrogen peroxide and superoxide production, but to a lesser extent. Leaf osmotic potential values of seedlings treated with the salt solutions were lower than the control.
\end{abstract}

The online version of the original article can be found under doi:10.1007/s13580-017-0194-1 